\title{
Subduction process of a fracture zone and aseismic ridges - the focal mechanism and source characteristics of the New Hebrides earthquake of 1969 January 19 and some related events
}

\author{
Wai-Ying Chung and Hiroo Kanamori Division of Geological and \\ Planetary Sciences, California Institute of Technology, Pasadena, Califomia 91125
}

Received 1977 December 19; in original form 1977 September 12

Summary. The subduction of the D'Entrecasteaux fracture zone-aseismic ridge system in the New Hebrides island arc is investigated on the basis of the focal process of the New Hebrides earthquake of 1969 January $19\left(m_{\mathrm{b}}=6.4\right.$, $h=107 \mathrm{~km}$ ), mechanisms of some related events, seismicity and regional tectonics. A notable feature of this island arc is the discontinuity of the New Hebrides Trench in the central New Hebrides where the ridge-fracture zone is subducting and intersecting the arc. The 1969 New Hebrides earthquake occurred along the subducted portion of the fracture zone and is characterized by unusual waveforms with remarkably large excitation of long-period waves, rare for earthquakes of comparable $m_{\mathrm{b}}$ and depth; the $P$-wave records show anomalously long duration and complexity indicating that the earthquake was a multiple event with a source duration of at least 30 s. $P$-wave first motions, seismicity data and synthetic body-wave seismograms indicate that the earthquake represents transverse left-lateral motion on a nearly vertical, E-W trending fault plane with a slip vector subparallel to the down-dip direction of the Benioff zone. The total seismic moment is found to be $5 \times 10^{26}$ dyne $\mathrm{cm}$ by matching the amplitudes and waveforms between observed and synthetic surface waves. The location and mechanism of this earthquake suggest that the D'Entrecasteaux fracture zone structurally extends to the east of the trench. This structural boundary at depth seems to be reflected in the spatial distribution of two earthquake swarms which are bounded sharply at the latitude of $15.2^{\circ} \mathrm{S}$. At the extension of the ridgefracture zone, the activity of intermediate-depth earthquakes, which are characterized by a very consistent pattem of down-dip extensional mechanism, is much higher and their depths are systematically shallower than in the adjacent regions. These features can be interpreted as a consequence of subduction of a buoyant ridge and the resultant increase in the extensional stress at the intermediate depths of the sinking slab. Fault-plane solutions of 22 earthquakes suggest that the subduction of aseismic ridges in the New Hebrides is characterized by high-angle thrusts. The lithospheres on the two sides of the D'Entrecasteaux fracture zone under the arc subduct more or less independently and generate alternating left-lateral and rightlateral earthquakes along the subducted portion of the fracture zone. 


\section{Introduction}

Within the framework of plate tectonics, earthquake activity near converging plate boundaries has been explained as a consequence of interaction between plates. Investigation of earthquake focal mechanisms and seismicity patterns provides valuable information about the nature of plate interaction, deformation and consequent strain release at plate boundaries. In most models of plate interaction used previously, oceanic plates are considered to be homogeneous and isotropic. However, oceanic plates are far from uniform; features such as fracture zones, sea mounts and aseismic ridges are frequently seen on the oceanic lithosphere. Because of this heterogeneity different parts of the oceanic plate may behave differently in subduction and plate-interaction processes. For instance, an aseismic ridge usually has a lower density compared to other portions of the oceanic plates. Structural roots have been found under uplifted features on the ocean floor indicating that such regions have densities intermediate between oceans and continents (Den et al. 1971; Ludwig et al. 1973; Kelleher \& McCann 1976). Because of their lower density compared to normal oceanic lithosphere, aseismic ridges may tend to resist subduction or subduct in a different way. Previous workers have suggested that the subduction process seems to be modified and the geometry of plate boundary can be affected by subduction of aseismic ridges because of the associated buoyant force. Vogt (1973) and Vogt et al. (1976) studied the effect of ridge subduction on the shape of the overriding island arc and the associated seismicity. They found that aseismic ridges often trend into cusps or irregular indentations in the trace of the subduction zone. They also found that a region of reduced seismicity seems to be associated with many consumed ridges. Kelleher \& McCann (1976) found that at locations where bathymetric highs, or aseismic ridges intersect with active trenches, large shallow earthquakes occur less frequently and have generally smaller rupture lengths than events along adjacent segments of the plate boundary. In this paper, the interaction between a trench and a subducting ridge-fracture-zone system and its consequent tectonic movements and earthquake source characteristics are investigated through a detailed study of the New Hebrides earthquake of 1969 January 19 (origin time: $18^{\mathrm{h}} 50^{\mathrm{m}} 52.4 \pm 0.37^{\mathrm{s}}$, GCT; latitude $14.89 \pm 0.021^{\circ} \mathrm{S}$ and longitude $167.22 \pm 0.018^{\circ} \mathrm{E}$ ), earthquake focal mechanisms, seismicity as well as tectonic features in the New Hebrides island arc. The New Hebrides earthquake of 1969 January 19 (hereafter called the New Hebrides earthquake) appears to be an abnormal event because of its unusual waveforms with prominent excitation of longperiod waves. Seismological data and tectonic setting suggest that the earthquake occurred on the subducted portion of the D'Entrecasteaux fracture zone, which has a topographic ridge (or aseismic ridge) on each side of it. Detailed analysis of this event will therefore not only improve our understanding of the source of this unusual earthquake but also provide important clues to the subduction process of fracture zone and aseismic ridges.

\section{Regional setting of the New Hebrides island arc}

The New Hebrides island arc is a member of the western Pacific island-arc system characterized by high seismicity and intense volcanic activity. With its centre at about $16^{\circ} \mathrm{S}$ and $168^{\circ} \mathrm{E}$ (Fig. 1), the New Hebrides arc extends south from the Santa Cruz Islands at $11^{\circ} \mathrm{S}$ to the islets Mathew and Hunter at $22^{\circ} \mathrm{S}$. The dip of the subducted plate steepens very rapidly under the New Hebrides arc compared with many other island arcs; the Benioff zone dips toward ENE with a dip angle of about $70^{\circ}$ (Santo 1970; Dubois 1971) in contrast with those of most of the western Pacific island arcs which dip toward the west. Earthquake swarms are very common; shallow shocks often occur closely both in time and space (Santo 1970). The most remarkable feature of this island arc is perhaps the discontinuity of the 


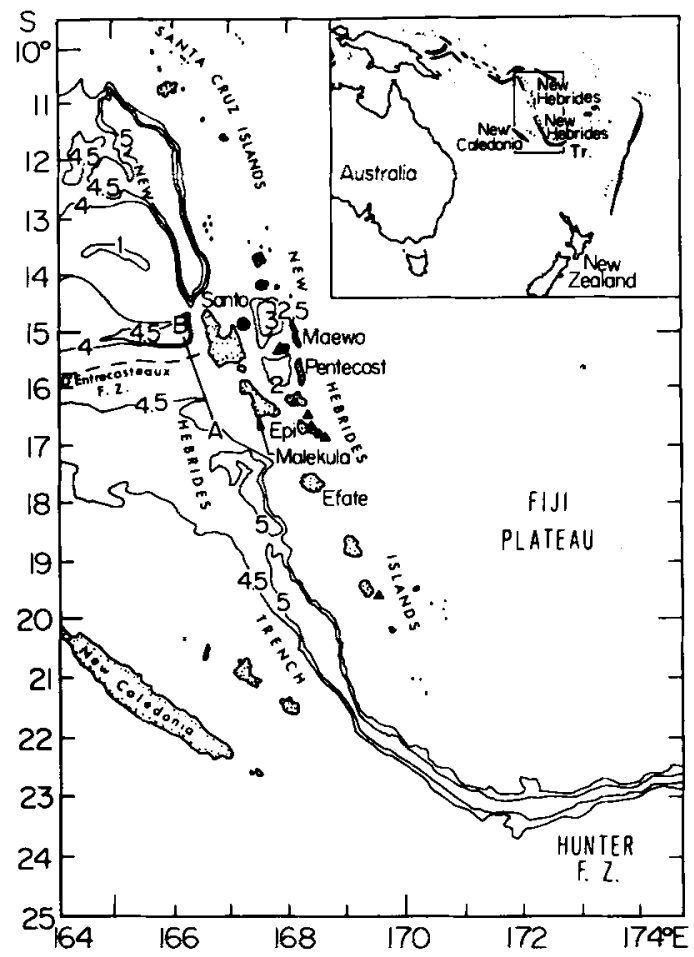

Figure 1. The New Hebrides island-arc system and related features. $\odot$ is the epicentre of the $1969 \mathrm{January}$ 19 earthquake; $\wedge$ represents historically active volcanoes. Submarine contours are in kilometres. The dashed line shows the approximate trace of the fracture zone.

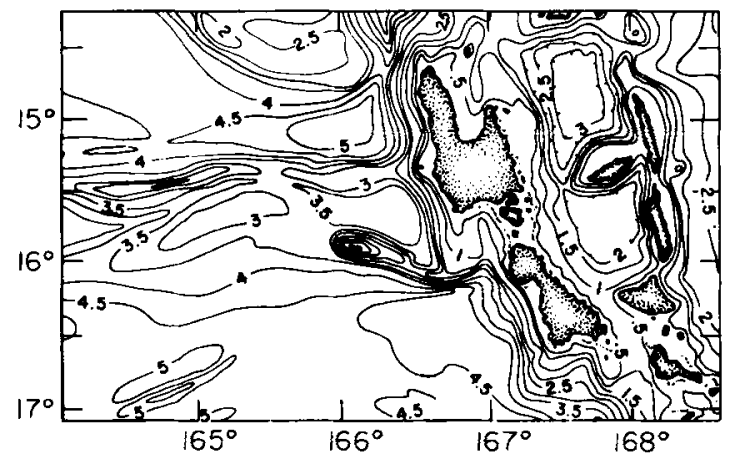

Figure 2. Bathymetry of the New Hebrides island arc and its vicinity. Contour interval is $0.5 \mathrm{~km}$ (after Chase 1971).

New Hebrides Trench in the central New Hebrides (Figs 1 and 2) where a transverse feature called D'Entrecasteaux fracture zone (Mallick 1973; Luyendyk, Bryan \& Jezek 1974) with a topographic ridge on each side of it intersects the island arc. Despite the interruption of the trench, earthquakes occur to depths of at least $250 \mathrm{~km}$ under the entire length of the arc system suggesting that the two trench sections belong to a single subduction zone or a single island-arc system. The ridges associated with the D'Entrecasteaux fracture zone are aseismic ridges and are distinct from seismically active mid-ocean ridges. There are several kinds of aseismic ridges on the sea floor, e.g. hot-spot traces (Wilson 1965; Morgan 1971, 


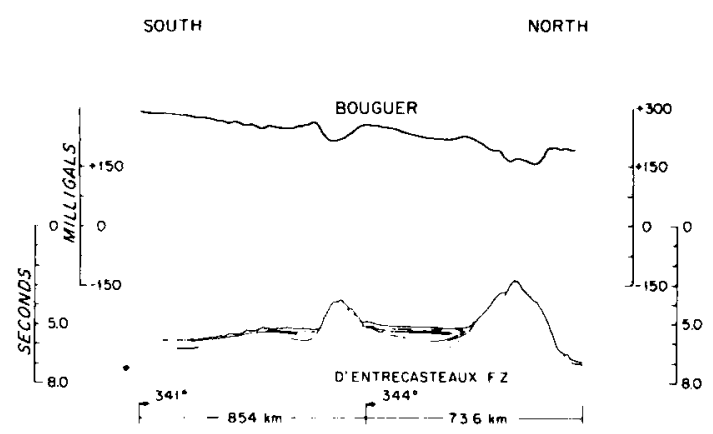

Figure 3. Bouguer anomaly and two-way travel time from surface to ocean bottom of seismic wave across line AB of Fig. 1 (after Luyendyk et al. 1974).

1972, 1973), fracture ridges (Menard \& Chase 1970) or remnant arcs (Karig 1972). The ridges discussed in this paper are the kind associated with a fracture zone or fracture ridges. Fig. 3 shows the bathymetry and gravity along line $A B$ of Fig. 1, perpendicular to the D'Entrecasteaux fracture zone. Bouguer gravity anomalies show relative minima of about 30 to $40 \mathrm{mgal}$ over the crests of the ridges suggesting low-density structural roots under the ridges. More details about the geological setting and tectonic evolution of the New Hebrides island arc are given by Mitchell \& Warden (1971); Karig \& Mammerickx (1972); Mallick (1973); Luyendyk et al. (1974) and Chung \& Kanamori (1978).

\section{Special characteristics of the body and surface waves}

The New Hebrides earthquake had a focal depth of $107 \mathrm{~km}$ and $m_{\mathrm{b}}=6.4$ according to our redeterminations ( $m_{\mathrm{b}}=6.2$ according to ISC Bulletin). This earthquake is remarkable for its unusual waveforms with prominent long-period body waves and surface waves which are rare for intermediate earthquakes of comparable depth and $m_{\mathrm{b}}$. The difference is apparent in Fig. 4. In this figure seismograms of the New Hebrides earthquake recorded at Pasadena, California by three types of seismograph having different passbands are compared with those of intermediate-depth earthquakes from other regions. The seismographs used are the Benioff short period ( $1-0.2)$, the long-period Benioff $(1-90)$ and the Press-Ewing seismograph (30-90) which sample seismic wave energies at high, intermediate and low-frequency bands respectively. In order to demonstrate the difference in the excitation at different periods between different events, the maximum amplitude of direct $\boldsymbol{P}$ of the Benioff $1-90$ records for all the events is normalized to a common value while the amplitude ratio between different kind of seismograms for each event is preserved. The ratio of the maximum amplitudes of long-period to short-period record for the New Hebrides earthquake is about 30 times greater than that of the 1964 November 2 event which occurred in North Peru and is, on the average, more than one order of magnitude larger than the other four events. The long duration of the seismogram of the New Hebrides event is also notable. This long duration of the seismogram indicates that the earthquake is a very complicated multiple event. The unusual waveform cannot be attributed to the crustal effect under the recording station because the waveform for other earthquakes is relatively simple. The New Hebrides earthquake also generated long-period surface waves of about 80 to $100 \mathrm{~s}$ which were recorded by all the WWSSN stations; most intermediate shocks with comparable $m_{\mathrm{b}}$ usually excite small or undetectable surface waves. Fig. 5 displays two sample records of G1 and R1 from the earthquake. 


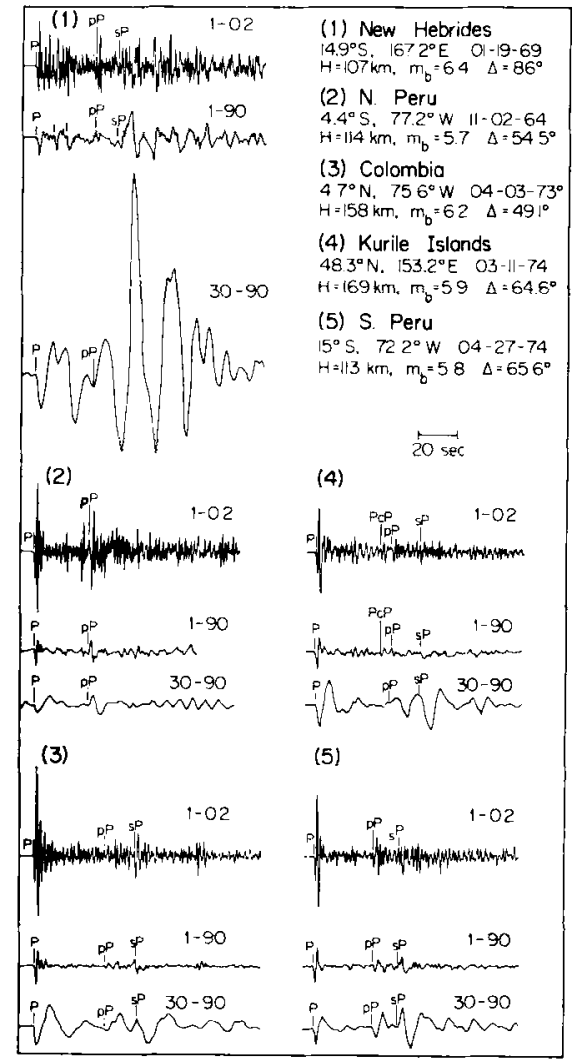

Figure 4. A comparison of the New Hebrides intermediate-depth earthquake with other intermediate events occurring in other seismic zones. All the seismograms are normalized vertical components recorded at Pasadena, California.

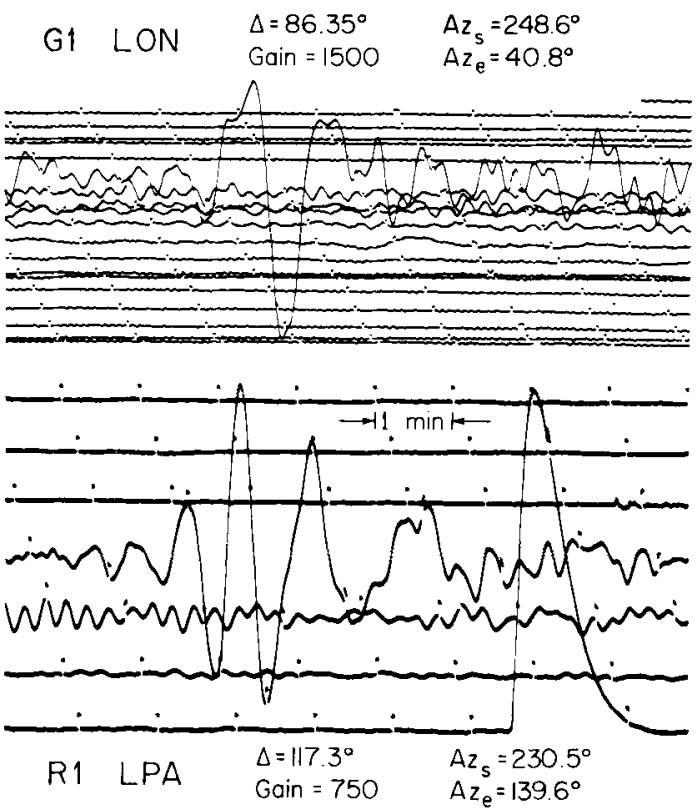

Figure 5. Love waves, $G 1$ and Rayleigh waves, R1, recorded by the long-period seismographs at LON and LPA respectively. 


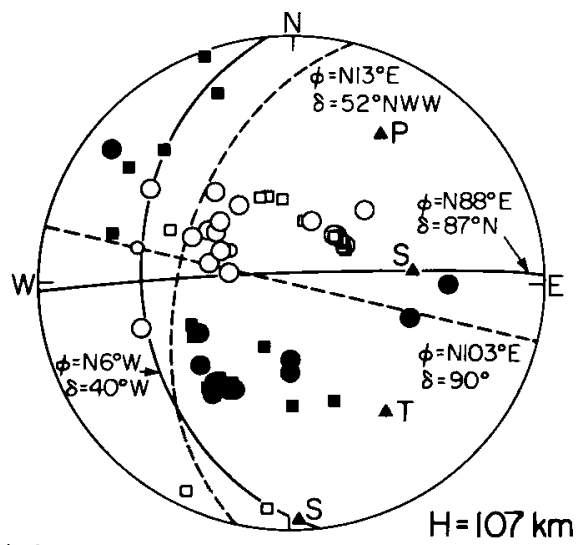

(2) Jan 19, $196914.89^{\circ} \mathrm{S}, 167.22^{\circ} \mathrm{E}$

Figure 6. Equal area projection of $P$-wave first motions on the lower hemisphere. Open circles and squares represent dilations recorded by WWSSN stations and non-WWSSN stations respectively. Closed circles and squares represent compressions read from WWSSN and non-WWSSN stations respectively. Large symbols are more reliable data. Compressional and tensile axes and slip vectors are represented by solid triangles with labels $P, T$ and $S$ respectively. $\phi$ and $\delta$ stand for strike and dip angle respectively. The number at the lower-left corner is the earthquake number used in Table 1 . The solid curves represent the $P$-wave mechanism, while the dashed curves show the mechanism obtained from surface-wave data.

\section{Fault-plane solution and alignment of earthquake hypocentres}

The fault-plane solution of the New Hebrides earthquake is constrained very well, as shown in Fig. 6. Twenty-seven $P$-wave first motions from the long period WWSSN records and one first motion from the Press-Ewing seismogram at Pasadena are used. Fifteen $P$-wave first motions reported in the ISC Bulletin are also used. The focal depth reported by ISC is $114 \pm 3.6 \mathrm{~km}$. Comparison of the observed records with the synthetic seismograms of $P$ and $p P$ suggests a depth of about $100 \mathrm{~km}$. In view of the uncertainty of the velocity structure in the vicinity of the source region we use the average focal depth, $107 \mathrm{~km}$. If only $\boldsymbol{P}$-wave first motions are used, the strike of the steeply dipping nodal plane can be moved by several degrees. However, this plane is further constrained by $\boldsymbol{P}$-wave synthetic seismograms, as will be discussed later. The strike and dip of this plane are determined to be $\mathrm{N} 88^{\circ} \mathrm{E}$ and $87^{\circ} \mathrm{N}$ respectively while the other nodal plane strikes $\mathrm{N} 6^{\circ} \mathrm{W}$ and dips $40^{\circ}$ to the west. Fig. 7(a) shows the distribution of epicentres of earthquakes which occurred during the seven-month period after the New Hebrides event. The data are taken from the USGS and ISC catalogues. Their magnitudes range from 4.3 to 5.4 . The overall distribution of the epicentres is along a trend with a strike of about $N 76^{\circ} \mathrm{E}$ which agrees well with that of the nearly vertical nodal plane of the New Hebrides earthquake (Fig. 6). Fig. 7(b) shows the projection of the same set of earthquake hypocentres on to a vertical plane perpendicular to the trend of the epicentres. The vertical alignment of the hypocentres suggests that the vertical EW striking nodal plane represents the fault plane of the New Hebrides earthquake.

\section{Interpretation of far-field body-wave seismograms}

In order to investigate the details of the multiple shock sequence of the New Hebrides earthquake long-period $\boldsymbol{P}$-wave seismograms recorded by the WWSSN are interpreted by using synthetic seismograms. Far-field seismograms which include $P, p P$ and $s P$ from a double couple or shear dislocation point source in a homogeneous half-space are synthesized by 

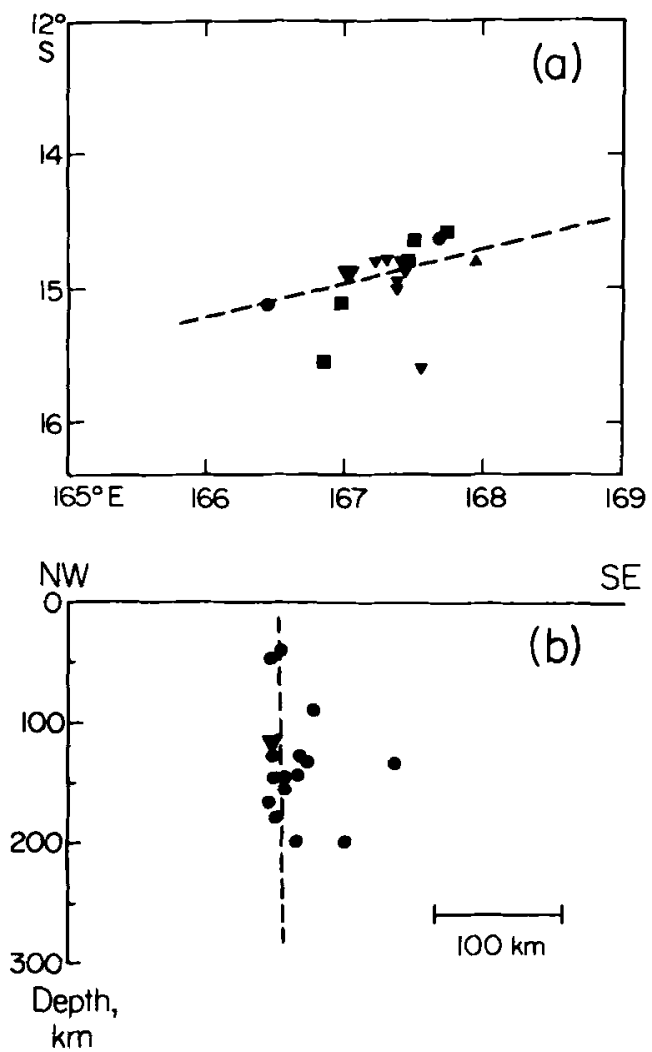

Figure 7. (a) Different symbols represent events of different depth $(h)$ ranges: $\bullet: 0<h<50 \mathrm{~km}$; 4 : $50<$ $h<100$; $: 100<h<150 ; \backsim: 150<h<200 ; \bullet: 200<h<250$. The large $\nabla$ is the 1969 January 19 event. The dashed line shows the trend of the epicentre distribution. (b) Projection of all of hypocentres in (a) on a vertical plane perpendicular to the dashed line in (a).

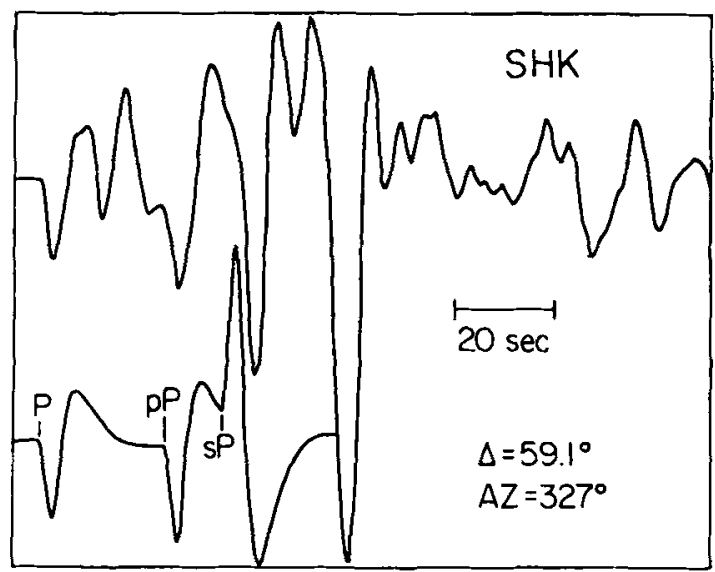

Figure 8. A comparison of the observational record of the New Hebrides event recorded at SHK with a synthetic seismogram. The New Hebrides earthquake appears to be a very complicated multiple shock.

using the method described in Langston \& Helmberger (1975) and Helmberger (1974). The upper part of Fig. 8 shows a sample of the long-period WWSSN records. The lower part of the figure is a synthetic seismogram from a point source having a ramp dislocation with a rise time of $3 \mathrm{~s}$ and a depth of $100 \mathrm{~km}$. For the velocity in the half-space, we used the velocity 


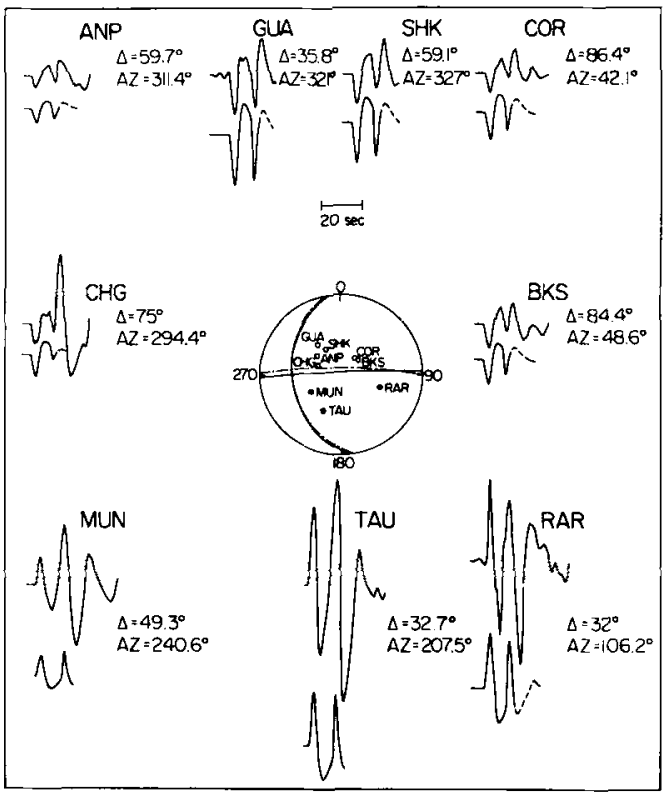

Figure 9. Observed $P$ waveforms (upper traces) and matched synthetics (lower traces). Only the first $14 \mathrm{~s}$ (before the first $p P$ arrival) are matched. The fault-plane solutions of the first and the second shocks are presented by solid and dashed curves at the centre respectively. Closed and open circles give the locations and first motions of the nine stations used.

obtained from the Jeffreys' structure by averaging the velocity over the depth range from 0 to $100 \mathrm{~km}$. The approximate agreement of the $p P$ and $s P$ waveforms suggests that the depth of $100 \mathrm{~km}$ is reasonable. When the fault plane is nearly vertical, as in the case of the New Hebrides earthquake, $s \boldsymbol{P}$ is the predominant phase on the far-field record. From Fig. 8 it is obvious that a single source cannot explain the observed seismogram. The total duration of the synthetic $P, p P$ and $s P$ is only about $50 \mathrm{~s}$, while the duration of the observed seismogram is as long as $80 \mathrm{~s}$ suggesting a rupture duration as long as $30 \mathrm{~s}$. We try to fit the first $14 \mathrm{~s}$ of the vertical long-period records, which are free from the contamination of $p P$ and $s P$ of the first event, by using two point sources with ramp dislocations placed at the same location. The method of matching the waveform with the synthetics is similar to that described by Chung \& Kanamori (1976). The fault-plane solution of the first event is further constrained by simultaneously fitting the waveforms at nine stations (ANP, BKS, CHG, COR, GUA, MUN, RAR, SHK and TAU [Fig. 9]). The azimuthal coverage of the station is reasonably good. The pulse that follows the first one with the same polarity is interpreted as the second event. In fitting the waveform of the second event, we first used the same focal mechanism as the first event and then slightly adjusted it to obtain a better fit. Fig. 9 compares the observed record with the synthetics computed for the first two events. The source parameters of the first and second events are determined as follows: strike $\phi_{1}=\mathrm{N} 88^{\circ} \mathrm{E}, \phi_{2}=\mathrm{N} 91^{\circ} \mathrm{E} ;$ dip angle $\delta_{1}=87^{\circ} \mathrm{N}, \delta_{2}=83^{\circ} \mathrm{N}$; slip angle $\lambda_{1}=50^{\circ}, \lambda_{2}=50^{\circ}$; seismic moment $m_{01}=1.8 \times 10^{26}$ dyne cm, $m_{02}=2.3 \times 10^{26}$ dyne cm; rise-time $\tau_{1}=3 \mathrm{~s}$, $\tau_{2}=2 \mathrm{~s}$. The difference in the origin time between the first and the second shock is about $10.5 \mathrm{~s}$. Since the accuracy of the determination of rise time is about one second, the difference between $\tau_{1}$ and $\tau_{2}$ is of marginal significance. The above result suggests that after the first break a larger fracture took place with a slight change in the strike direction. It was further followed by more energetic ruptures which appear as the large swings in the later 
parts of the records (Figs 4 and 8). The seismic moments of the later events seem to be even larger than those of the first two. This is similar to the case of the Spanish deep-focus earthquake of 1954 (Chung \& Kanamori 1976).

\section{Source parameters and rupture process from surface waves}

An important set of data of the earthquake comes from long-period surface waves, G1 and $\mathrm{R} 1$, which are recorded at many WWSSN stations with a good azimuthal coverage. Longperiod surface waves provide reliable information about the overall characteristics of the source. In this paper the gross source parameters and faulting process of the New Hebrides event are extracted from surface waves by using the method described in Kanamori (1970a) (see also Kanamori \& Cipar 1974; Kanamori \& Stewart 1976). The vertical components of Rayleigh waves are windowed between group velocities of 3.23 and $4.35 \mathrm{~km} / \mathrm{s}$ while the two horizontal components of Love waves are windowed from 3.71 to $4.76 \mathrm{~km} / \mathrm{s}$ and are combined to obtain the transverse component. After low-pass filtering is applied to remove the components with periods shorter than $40 \mathrm{~s}$ the seismograms are equalized to a distance of $90^{\circ}$ and to a magnification of 1500 . The earth model $5.08 \mathrm{M}$ (Kanamori (1970b) and $Q$ values in Figure 14 of Kanamori \& Stewart (1976) (which is based on the data of Smith 1972 and Tsai \& Aki 1969) were used in the above equalization and the later synthesis of surface waves. For intermediate-depth events, the waveform of Love waves is sometimes complicated by higher modes, especially for a pure dip-slip source. However, for a source with large strike-slip component at a depth of about $100 \mathrm{~km}$, as in the case of the New Hebrides earthquake, the excitation of all the higher-mode Love waves is much smaller than those of the fundamental mode (Fukao \& Abe 1971). Thus the higher-mode contribution is neglected in our analysis. In fact, as will be shown later, the actual waveforms can be closely approximated by synthetic seismograms consisting of only fundamental modes. Figs 10 and 11 show the equalized $R 1$ and $G 1$ respectively. The radiation patterns of the maximum peak to peak trace amplitude are shown by the circular plots at the centre. The radiation pattern is two-lobed for Rayleigh waves and four-lobed for Love waves. The maximum amplitude of Love waves is slightly larger than that of Rayleigh waves. The difference in the group arrival times and the waveform from one station to another reflects the regional variation of velocity and $Q$ structure. In order to interpret these data, synthetic seismograms are computed for a point source at a depth of $107 \mathrm{~km}$ with a step dislocation

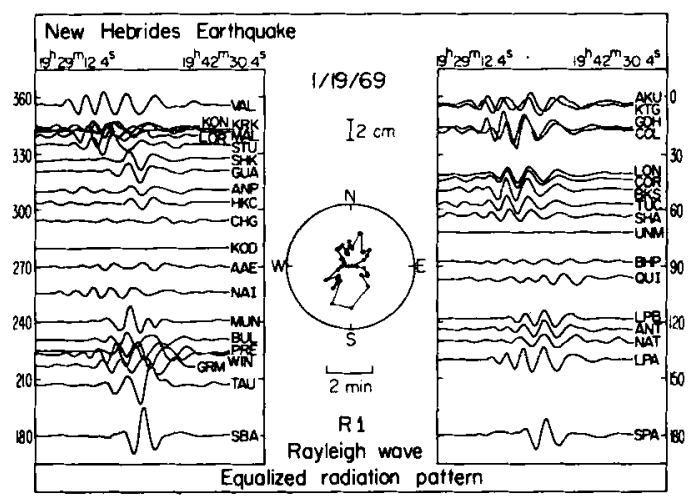

Figure 10. Rayleigh waves (R1) equalized to a propagation distance of $90^{\circ}$. The vertical scale gives the amplitude on the standard $15-100$ seismogram with a magnification of 1500 . Upward motion is taken positive. 


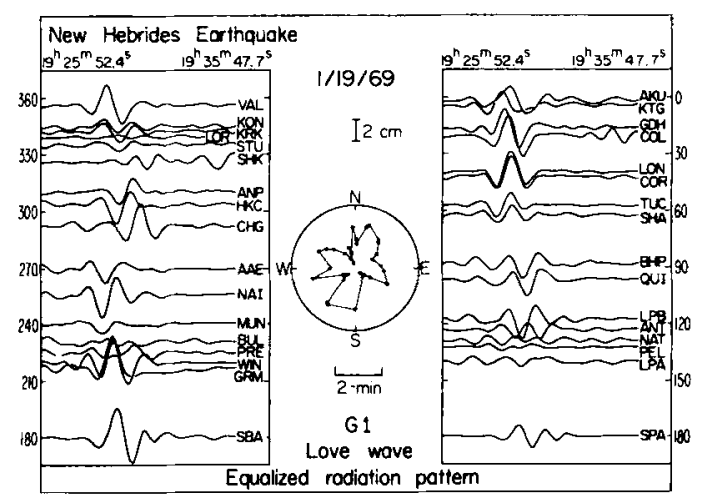

Figure 11. Love waves (G1) equalized to a propagation distance of $90^{\circ}$. The vertical scale gives the amplitude on the standard 15-100 seismogram with a magnification of 1500 . Clockwise motion around the source is taken positive.
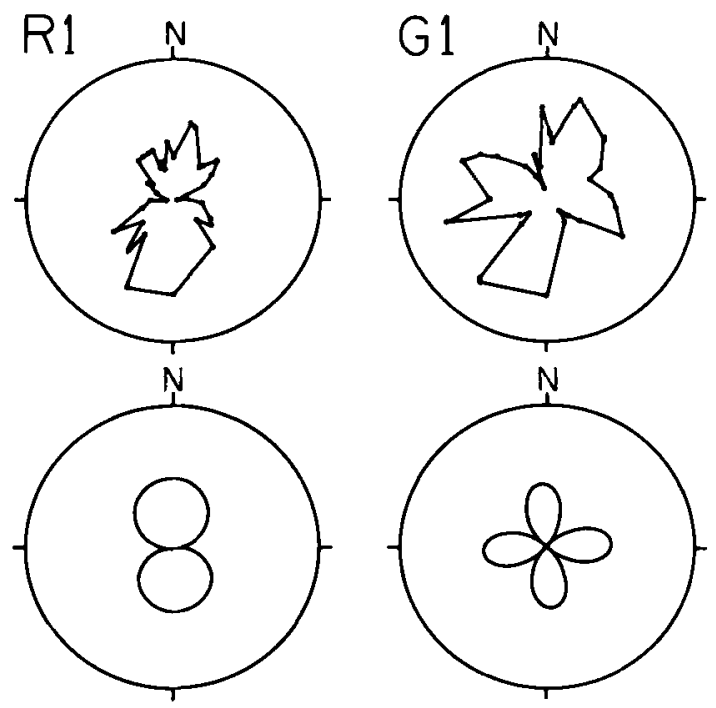

Figure 12. A comparison of the observed radiation patterns of $R 1$ and $G 1$ (top) with the synthetic patterns (bottom) generated from a point source with a step dislocation and the focal mechanism determined from $P$-wave data.

and the focal mechanism determined from the $P$-wave data. As shown in Fig. 12, neither the lobe direction nor amplitude ratio of $\mathrm{G} 1$ to $\mathrm{R} 1$ can be explained by this source model. Starting from this model, a better model was searched by changing the strike azimuth, slip vector and dip angle slightly. We found that a mechanism with fault strike $=\mathrm{N} 103^{\circ} \mathrm{E}$, dip angle $=90^{\circ}$ and slip angle $=38^{\circ}$ can explain the data reasonably well (Figs 13 and 14). A seismic moment of $5 \times 10^{26}$ dyne $\mathrm{cm}$ is obtained. This moment is relatively large for earthquakes of comparable magnitude. As shown in Fig. 6, this mechanism is considerably different from the $\boldsymbol{P}$-wave mechanism. Since $\boldsymbol{P}$ waves and surface waves carry information at different periods, the surface-wave mechanism should not necessarily be identical to the $P$-wave mechanism. In particular, for a complex event such as the New Hebrides earthquake in which the first event is relatively small, it is not surprising that the overall mechanism represented by surface waves is considerably different from that of the very beginning of the rupture. 


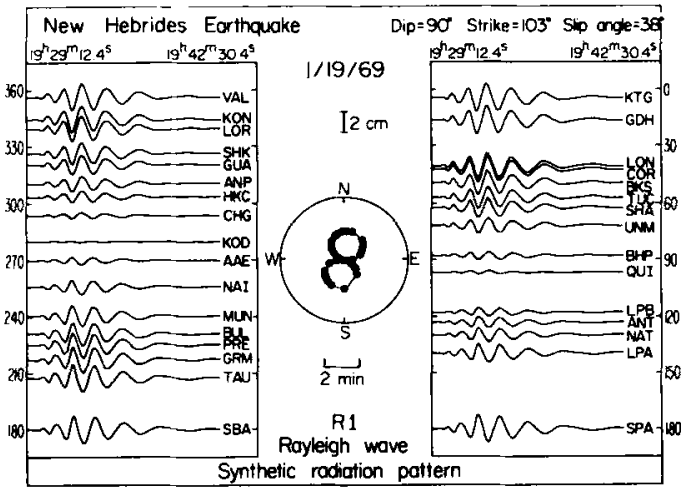

Figure 13. Synthetic Rayleigh waves (R1) at a propagation distance of $90^{\circ}$. The vertical scale is the same as that in Fig. 10.

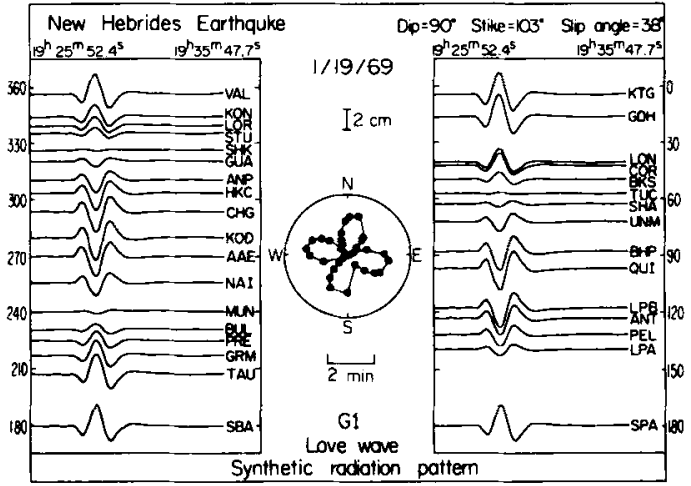

Figure 14. Synthetic Love waves (G1) at a propagation distance of $90^{\circ}$. The vertical scale is the same as that in Fig. 11.

The seismic moment determined from surface waves is only slightly larger than the sum of the moments of the first two events. Since the body waves from later events are very large (Figs 4 and 8), one would expect a much larger surface-wave moment than the sum of the first two events. However, this discrepancy is not surprising in view of the uncertainty in the determination of body-wave moment; a factor of 2 to 4 scatter is not uncommon.

\section{Spatial distribution of two earthquake swarms}

As shown in the previous sections, the New Hebrides earthquake occurred on the extension of the subducting D'Entrecasteaux fracture zone and its fault motion has a large strike-slip component, in the down-dip direction of the Benioff zone, on a vertical fault plane parallel to the fracture zone. This mechanism suggests that the D'Entrecasteaux fracture zone structurally extends to the east of the trench, the earthquake representing displacement along the subducted portion of the fracture zone. Vertical fault-like features within the subducted plate in this area has been pointed out by Isacks \& Barazangi (1977); Chung \& Kanamori (1977) and Isacks et al. (1977). It is interesting to note that two earthquake swarm activities, one from 1965 July 23 to October 4 and the other from 1973 December 28 to 1974 February 14 are spatially bounded by a parallel at $15.2^{\circ} \mathrm{S}$, the extension of the D'Entrecasteaux fracture zone (Fig. 15). It is possible that this sharp boundary is a surface manifestation of the structural boundary in the subducted fracture zone at depths. 


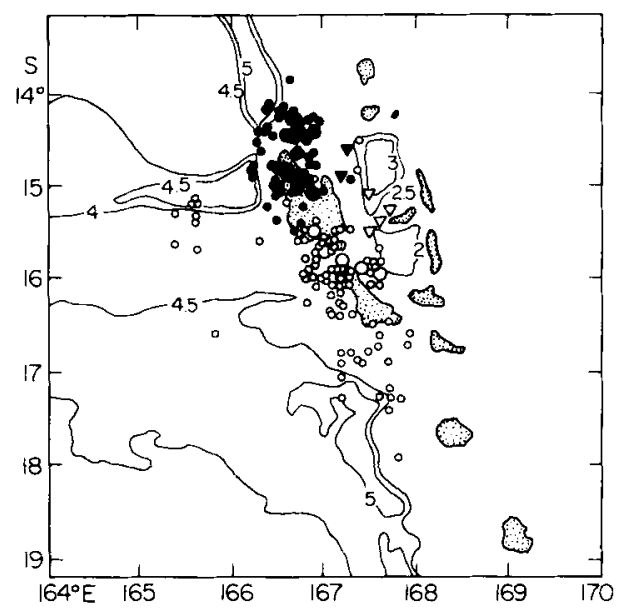

Figure 15. Closed and open symbols represent events of the swarms of 1973 and 1965 respectively while circles and triangles stand for shallow and intermediate shocks respectively.

\section{Seismicity pattern associated with ridge subduction}

Kelleher \& McCann (1976) studied the distribution of great shallow earthquakes along subduction zones and their relations with aseismic ridges and bathymetric highs. They pointed out that the zones where aseismic ridges intersect with active trenches are characterized, in many instances, by gaps of intermediate depth hypocentres. Vogt et al. (1976) studied the effect of subduction of aseismic ridges on seismicity and found that a region of reduced seismicity seems to be associated with many consumed ridges. Since the foregoing analyses suggest that the D'Entrecasteaux fracture zone is subducting beneath the New Hebrides arc, detailed analysis of seismicity in this region would provide further information regarding the nature of ridge subduction. Fig. 16 shows the distribution of all the epicentres of intermediate events (focal depth between 90 to $270 \mathrm{~km}$ ) which occurred in the period from 1970 December 1 to 1974 December 31 in the area. The data are taken from the USCGS and ISC catalogues. We divide the region into three zones. Zone 1 is from

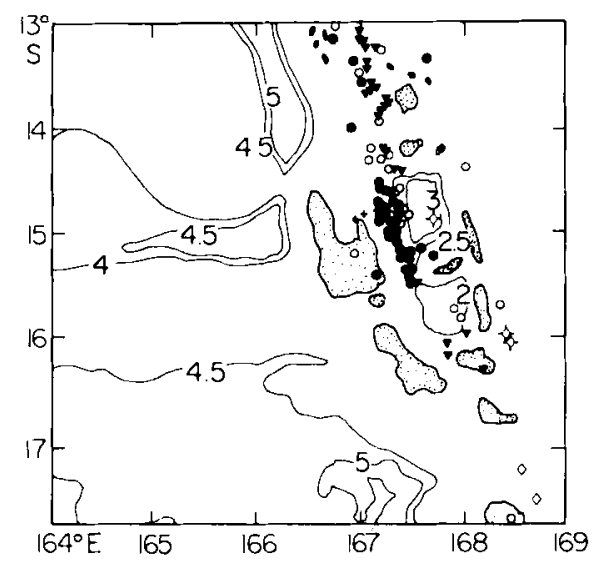

Figure 16. Different symbols represent events of different depth $(h)$ ranges: $+: 95<h<110 \mathrm{~km}$; $\bullet$ : $110 \leqslant h<150 ; 0: 150 \leqslant h<180 ; \nabla: 180 \leqslant h<220 ; \diamond: 220 \leqslant h<230 ; \diamond ; 230 \leqslant h<270$. Submarine contours are in kilometres. 


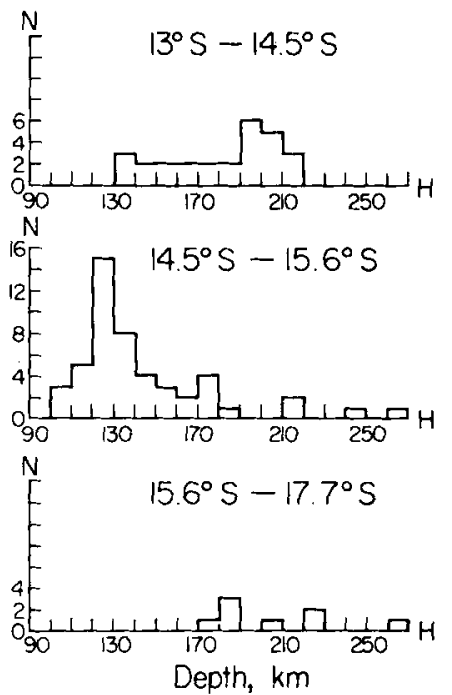

Figure 17. $N$ and $H$ represent number of earthquakes and focal depth respectively.

13 to $14.5^{\circ} \mathrm{S}$, an area to the north of the ridge fracture-zone; zone 2 is 14.5 to $15.6^{\circ} \mathrm{S}$, the extension of the ridge and zone $3,15.6$ to $17.7^{\circ} \mathrm{S}$, an area to the south of the ridge. It is clear that the earthquakes on the extension of the ridges (zone 2) are shallower than those occurring to the north and to the south. Fig. 17 presents histograms of the focal-depth distribution in the three zones. The difference in the focal-depth distributions between the zone along the ridge extension and those on the two sides of it is clear. The peak of the distribution is at 120 to $130 \mathrm{~km}$ in zone 2 while it is at a much larger depth in zones 1 and 3. It is also remarkable that the activity at the intermediate depth is very high in zone 2 . The seismicity in this region has been also studied by Santo (1970). The seismicity pattern discussed above is clearly seen in Santo's (1970) Figure 6. Santo also noted that the dip angle of the Benioff zone is about $65^{\circ}$ in the region where the trench is missing while it is $70^{\circ}$ along most parts of the New Hebrides arc. We interpret that the lower dip angle of the Benioff zone suggests that the Benioff zone is locally deformed or uplifted due to the upward pulling of the buoyant force while the relatively shallow depth of the seismic activity may be interpreted by a similar mechanism and/or by differential subduction near the location of ridge subduction with the lithospheres on the two sides of the D'Entrecasteaux fracture zone subducting faster than the portion with the ridges. An increase in resistance against subduction due to the buoyancy probably enhances the down-dip extensional stress in the slab causing higher seismic activity at the intermediate depth.

\section{Focal mechanisms between 14 and $16^{\circ} \mathrm{S}$, the New Hebrides islands and mode of strain release along a subducting ridge-fracture zone}

Focal mechanisms of intermediate and deep earthquakes of the New Hebrides region that occurred between 1962 and 1968 have been studied by Isacks \& Molnar (1971). Shallow earthquakes for the period from 1963 through part of 1969 have been investigated by Johnson \& Molnar (1972). In this paper we made focal mechanism determinations for 10 additional earthquakes that occurred in the central New Hebrides region, especially along the extension of the D'Entrecasteaux fracture zone. Fig. 18 presents 22 fault-plane solutions (Tables 1 and 2); numbers 1 to 10 are new solutions of the present study while numbers 


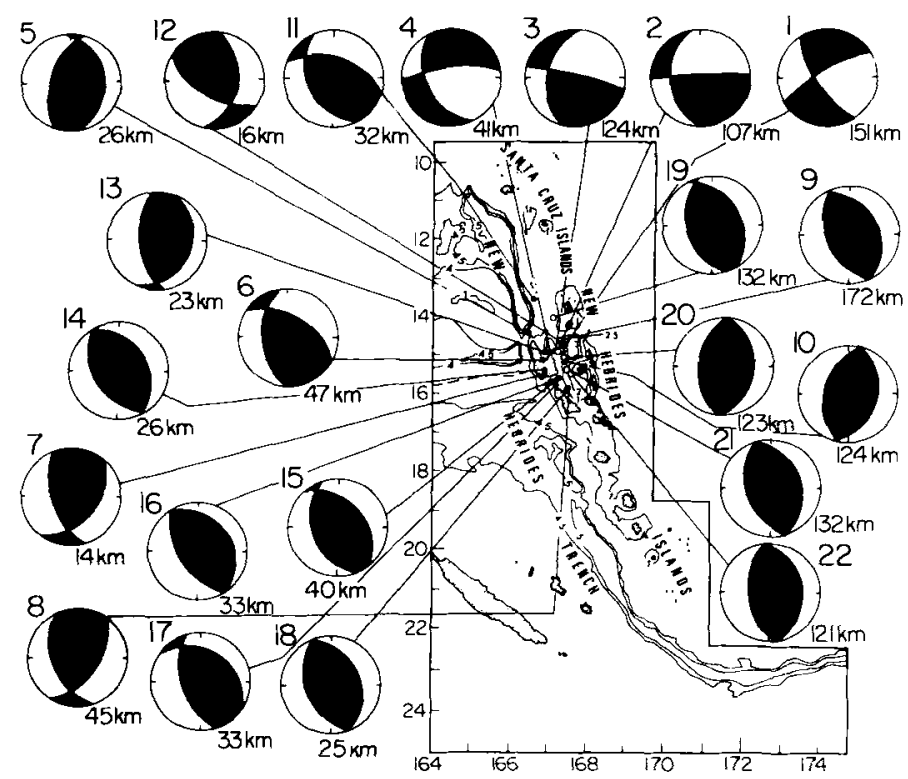

Figure 18. The dark quadrants are the $P$-wave compression first-motion quadrants on the lower hemisphere. Filled and unfilled circles represent shallow and intermediate events respectively. The numbers to the upper left and lower right of each fault-plane solution are event number and focal depth of the corresponding earthquake respectively. See the caption of Fig. 1 for the rest of the symbols and representations.

Table 1. Focal-mechanism parameter.

\begin{tabular}{|c|c|c|c|c|c|c|}
\hline Event & Date & $\begin{array}{l}\text { Location } \\
\left(^{\circ}\right)\end{array}$ & $\begin{array}{l}\text { Depth } \\
(\mathrm{km})\end{array}$ & $\begin{array}{l}\text { Strike } \\
\left({ }^{\circ}\right)\end{array}$ & $\begin{array}{l}\text { Dip } \\
\left({ }^{\circ}\right)\end{array}$ & $m_{\mathrm{b}}$ \\
\hline 1 & 1969 July 29 & $14.87 \mathrm{~S} 167.25 \mathrm{E}$ & 151 & $\begin{array}{l}240.7 \\
146.4\end{array}$ & $\begin{array}{l}76 \\
70\end{array}$ & 5.3 \\
\hline 2 & 1969 January 19 & $14.89 \mathrm{~S} 167.22 \mathrm{E}$ & 107 & $\begin{array}{l}268.0 \\
174.0\end{array}$ & $\begin{array}{l}87 \\
40\end{array}$ & 6.4 \\
\hline 3 & 1971 August 14 & $14.84 \mathrm{~S} 167.20 \mathrm{E}$ & 124 & $\begin{array}{l}284.5 \\
193.3\end{array}$ & $\begin{array}{l}89 \\
46\end{array}$ & 5.5 \\
\hline 4 & 1969 December 10 & $14.86 \mathrm{~S} 167.02 \mathrm{E}$ & 41 & $\begin{array}{l}263.8 \\
154.8\end{array}$ & $\begin{array}{l}73.5 \\
50\end{array}$ & 5.5 \\
\hline 5 & 1973 December 28 & $14.46 \mathrm{~S} 166.50 \mathrm{E}$ & 26 & $\begin{array}{l}354.0 \\
198.4\end{array}$ & $\begin{array}{l}33.4 \\
59.0\end{array}$ & 6.4 \\
\hline 6 & 1973 December 29 & $15.12 \mathrm{~S} 166.90 \mathrm{E}$ & 47 & $\begin{array}{l}175.9 \\
299.9\end{array}$ & $\begin{array}{l}51.1 \\
55.3\end{array}$ & 6.2 \\
\hline $7^{\star}$ & 1965 August 11 & $15.50 \mathrm{~S} 166.90 \mathrm{E}$ & 14 & $\begin{array}{r}38.5 \\
161.5\end{array}$ & $\begin{array}{l}47.5 \\
59.3\end{array}$ & 6.3 \\
\hline 8 & 1972 May 4 & $15.92 \mathrm{~S} 167.51 \mathrm{E}$ & 45 & $\begin{array}{c}35.5 \\
158\end{array}$ & $\begin{array}{l}47.7 \\
49.7\end{array}$ & 6.1 \\
\hline 9 & 1970 January 30 & $14.6 \mathrm{~S} \quad 167.30 \mathrm{E}$ & 172 & $\begin{array}{l}158.4 \\
333.0\end{array}$ & $\begin{array}{l}50.0 \\
40.1\end{array}$ & 5.7 \\
\hline 10 & 1973 November 30 & $15.2 \mathrm{~S} \quad 167.39 \mathrm{E}$ & 124 & $\begin{array}{r}16.4 \\
192.2\end{array}$ & $\begin{array}{l}38.7 \\
51.4\end{array}$ & 6.0 \\
\hline
\end{tabular}

Events 7 (this study) and 14 (Johnson \& Molnar 1972) - see Table 2 - represent the same earthquake. 
Table 2. Focal-mechanism parameters.

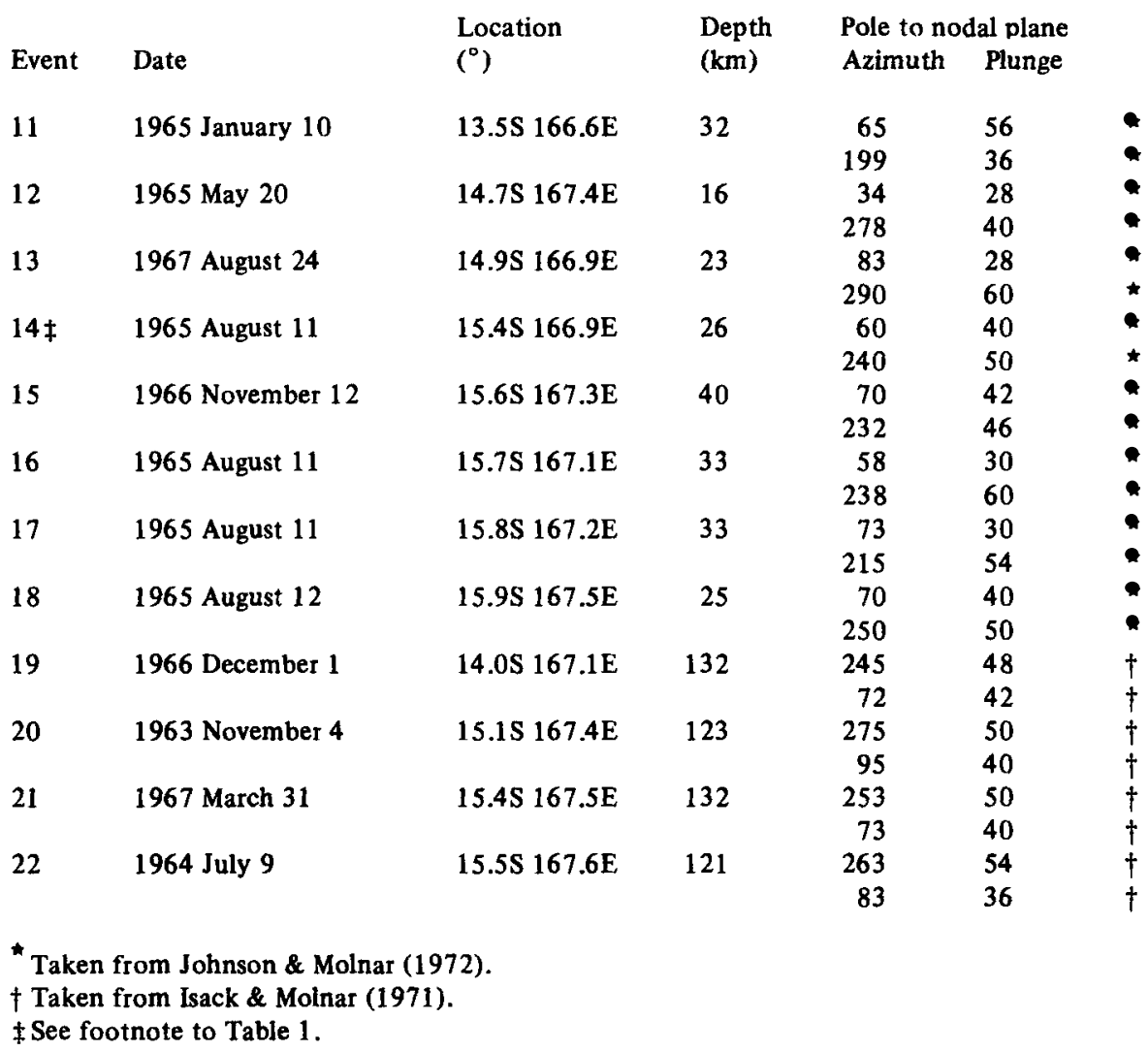

11 to 18 are taken from Johnson \& Molnar (1972) and numbers 19 to 22 from Isacks \& Molnar (1971). The first-motion data of direct $P$ used in our study are shown in Fig. 19. Most of the first-motion data are read from the WWSSN long-period records. In some cases the data reported by ISC and the WWSSN short-period records are used to supplement the first-motion data. There are two classes of fault-plane solutions in Fig. 18: thrust faults along the trend of the island arc and oblique strike-slip faults along the extension of the fracture zone. The distribution of the seismic stations is inadequate to constrain the $E$ or ENE dipping planes of some of the thrust events. Nevertheless their mechanisms are obviously high-angle thrust fault and show very consistent patterns; their dip angles and the slipvector orientation on the $\mathrm{E}$ or ENE dipping planes are about the same. The average dip angle is $43 \pm 10^{\circ}$ and the average azimuth and plunge of the slip vector are $N 71 \pm 17^{\circ} \mathrm{E}$ and $36 \pm 8^{\circ}$ respectively. Usually low-angle thrust faults are observed in island arcs such as Alaska and the Aleutian Islands (Plafker 1972; Stauder 1968; Kanamori 1970c), Kurile Islands (Stauder 1976; Kanamori 1970a), Japan (Kanamori 1971, 1972; Shimazaki 1974) and Chile (Plafker 1972; Kanamori \& Cipar 1974); the dip angle of these thrust events is usually 10 to $30^{\circ}$. But no mechanism of low-angle thrust faulting is found in the central New Hebrides, where the trench does not exist. Fig. 20 shows the topography of the central New Hebrides and the projections of the 22 earthquake foci of Fig. 18 on a vertical plane perpendicular to the island arc. All shallow events except events 12 and 18 and probably 


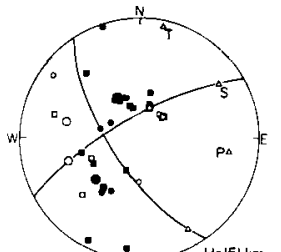

(1) why $29,9069487^{\circ} \mathrm{S}$. $\mathrm{H}^{+15 \mathrm{~km}} \mathrm{~km}$

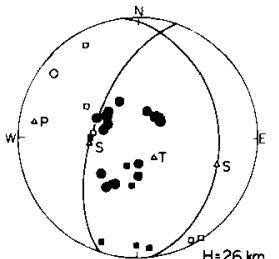

(5) Dec 28, $19731446^{\circ} \mathrm{S}, \mathrm{H}=26 \mathrm{~km}$

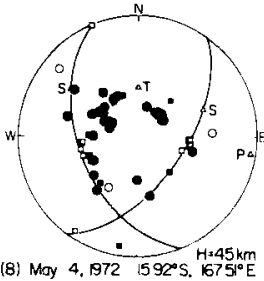

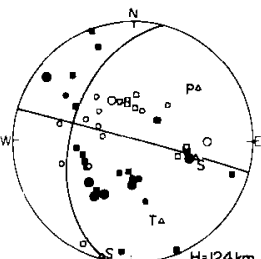

(3) Aug 14, 97 - $4.84^{\circ} \mathrm{S}, 1672^{\circ} \mathrm{E}$

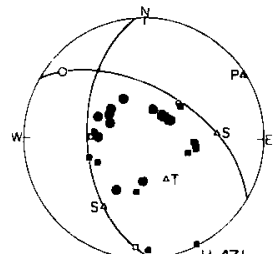

(6) Dec 29. 973 15125. $\begin{aligned} & 4=47 \mathrm{~km} \\ & 1669^{\circ} \mathrm{E}\end{aligned}$

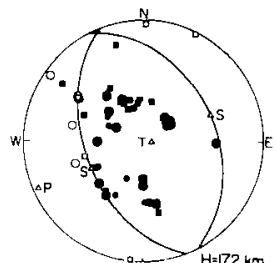

(9) Jan $30,070146^{\circ} \mathrm{S}$. $\mathrm{H}=173^{\circ} \mathrm{km}$

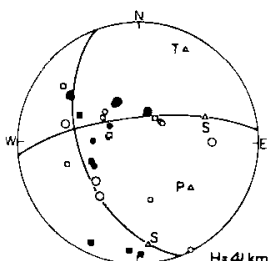

(4) Dec $10.19691486^{\circ} \mathrm{S}, 16702^{\circ} \mathrm{E}$

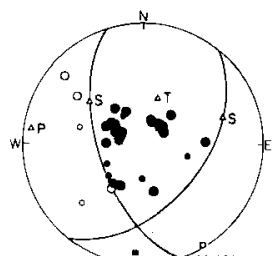

(7) Aug $11,965155^{\circ} \mathrm{S} \quad \begin{aligned} & \mathrm{H}=14 \mathrm{~km} \\ & 1669^{\circ} \mathrm{E}\end{aligned}$

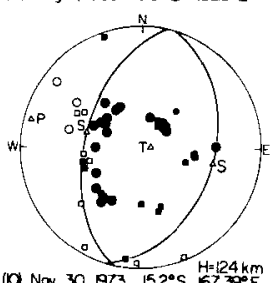

Figure 19. First motion data of $P$ waves on the lower hemisphere for the focal-mechanism solutions determined in this study. Symbols in this figure have the same meanings as those used in Fig. 6 .

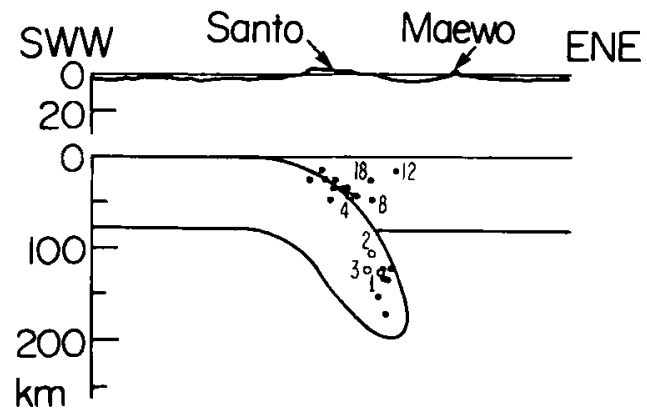

Figure 20. Closed and open circles stand for earthquakes with thrust faulting and strike-slip faulting respectively. Event numbers are given for some earthquakes.

event 8 , fall on an ENE dipping plate-boundary (dip angle $\approx 34^{\circ}$ for depth of about 20 to $50 \mathrm{~km}$ ). In view of this and their very consistent slip-vector directions, these earthquakes are considered to be interplate earthquakes. Their slip vectors then, represent the motions of the Australian plate relative to the overriding plate. Averaging the dip angles obtained from foci distribution and fault-plane solutions of these interplate events, the dip angle of the plate interface is determined to be about $38^{\circ}$ at the depth of about 20 to $50 \mathrm{~km}$. Focal mechanism of earthquakes which occurred to the north of $14^{\circ} \mathrm{S}$ and to the south of $16^{\circ} \mathrm{S}$ are characterized by high-angle thrust faulting as well as faulting with irregular orientation; typical low-angle thrusts are rare and are found only near the northern and southern ends of the arc (Chung, unpublished data). The high-angle thrusts predominate particularly at the section where aseismic ridges are subducting. The dip angles of the thrust-fault planes and the plunges of the slip vectors are larger in this arc than in many other subduction 
boundaries. This is probably a consequence of the abnormally rapid steepening of the subducted slab under this arc. On the other hand, events 12 and 18 and probably event 8 , represent intraplate earthquakes occurring in the overriding plate indicating that the compressional stress axes are about horizontal and trending from EW to ENE-SWW. All the intermediate-depth earthquakes, except events 1 to 4 , show very consistent down-dip extensional mechanisms. This is probably a feature associated with ridge subduction. Usually down-dip extension is considered to be due to the downward pull of the sinking oceanic plate due to its relatively high density compared with the surrounding mantle. In this region the low-density ridge at the upper part of the sinking slab resists subduction thereby enhancing the extensional stress in the down-going lithosphere.

The mechanism of the events with a large strike-slip component is constrained very well. Along the extension of the D'Entrecasteaux fracture zone there is an intermediate shock, event $3\left(m_{\mathrm{b}}=5.5, h=124 \mathrm{~km}\right)$ which has about the same mechanism as that of the 1969 January 19 earthquake, event 2 (Figs 18,19 and 6 and Table 1). There are two shocks, one shallow (event $4: h=41 \mathrm{~km}, m_{\mathrm{b}}=5.5$ ) and one intermediate-depth (event $1: h=151 \mathrm{~km}$, $m_{\mathrm{b}}=5.3$ ) whose mechanism is completely opposite to that of the two events mentioned above. The hypocentres of these four events have been relocated by using the master event method. Since event 2 is the largest shock it is used as a calibration earthquake and the hypocentres of events 1,3 and 4 are calculated with respect to it. The result indicates that the four earthquakes are on the extension of the D'Entrecasteaux fracture zone. The ENE striking nodal plane of event 1 is closer to the strike of the D'Entrecasteaux fracture zone than the other nodal plane. Also the EW striking plane of event 4 is subparallel to the strike of the fracture zone. If we take these nodal planes as the fault plane these events represent right-lateral slip along the fracture zone which is opposite to that represented by events 2 and 3. This result may seem somewhat unusual, but it may be explained in terms of differential subduction. Because of the buoyancy, the ridge-fracture-zone system encounters resistance upon subduction (Fig. 21). A slight difference in the resistance against the oceanic lithosphere to the north and to the south of the ridge-fracture-zone system may result in differential motion between these two lithospheres. When the oceanic lithosphere to the south of the ridge advances or subducts with respect to that to the north of it, a leftlateral faulting such as events 2 and 3 occurs along the subducted fracture zone. On the

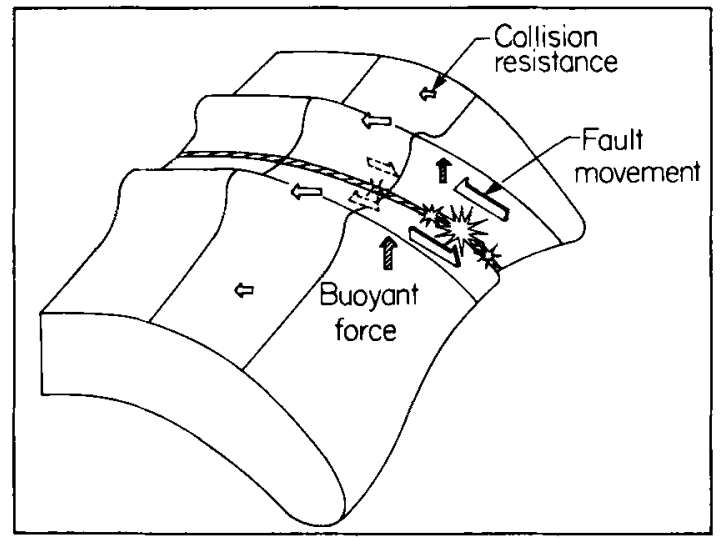

Figure 21. Schematic three-dimensional model for the subduction of a ridge-fracture-zone system and the associated tectonic movements. Large star stands for large earthquake; the longer the arrow the larger the quantity involved. 
other hand when the lithosphere to the north of the fracture zone advances, a right-lateral faulting such as events 1 and 4 occurs. This alternating motion along the subducted portions of the D'Entrecasteaux fracture zone may be the cause of the existence of the two mechanisms having an opposite sense of motion. This situation is illustrated schematically in Fig. 21 in which open arrows represent collision resistance of the overrriding plate against the subducting lithosphere, hatched arrows buoyant forces associated with the ridges, half arrows fault movements and stars earthquakes along the fracture zone. The larger the symbols, the larger the quantities involved. The stars outlined by solid lines and half arrows represent earthquakes 2 and 3 and the left-lateral displacement during the earthquakes whereas the dashed stars and dashed half arrows stand for events 1 and 4 and the associated right-lateral movement at different stages of plate subduction. The alternating left-lateral and right-lateral motions may be one of the characteristic tectonic movements associated with subduction of buoyant ridge-fracture-zone systems.

\section{Conclusions}

The New Hebrides earthquake of 1969 January 19, which occurred near the intersection of an aseismic ridge-fracture-zone system, the D'Entrecasteaux fracture zone and the New Hebrides Trench provided a unique opportunity for studying the subduction process of fracture zones and aseismic ridges. The earthquake is a complex multiple shock having a relative excitation of long-period body waves more than one order of magnitude larger than other common shocks of comparable $m_{b}$ and depth. The earthquake was initiated by a leftlateral motion on a vertical $\mathrm{E}-\mathrm{W}$ striking fault plane with a slip vector subparallel to the down-dip direction of the Benioff zone. The strike direction then, changed clockwise by $15^{\circ}$ during the rupture. The location, mechanism and complexity of this earthquake suggest that the earthquake represents faulting along the subducted portion of the D'Entrecasteaux fracture zone. The complexity may reflect a highly heterogeneous stress distribution along the fracture zone. The focal depths of intermediate-depth events are shallower and the dip angle of Benioff zone is smaller near the location of ridge-fracture-zone subduction than in the adjacent regions. These features can be interpreted as a consequence of differential subduction and local uplift of the Benioff zone caused by the buoyant force associated with the subduction of the low-density ridge. These intermediate-depth events have a very consistent pattern of down-dip extension mechanisms indicating that the extensional stress in the slab is enhanced by the resistance of the aseismic ridge against subduction. The lithospheres on either side of the fracture zone subduct more or less independently and generate alternate left and right-lateral earthquakes along the subducted portion of the fracture zone. This type of subduction has not been found prior to this study and may represent a process characteristic of subduction of fracture zones and aseismic ridges.

\section{Acknowledgments}

We are very grateful to Yoshio Fukao who made many valuable suggestions and kindly reviewed the manuscript. Discussions with Clarence Allen on the faulting mechanisms contributed to our interpretation of the data. Seiya Uyeda kindly reviewed the manuscript and made helpful comments on our tectonic model. Thomas Ahrens and Robert Geller are appreciated for reading the manuscript. We thank John Cipar for discussions as well as his suggestions for improvements of the manuscript. Useful discussions with Bernard Minster, James Whitcomb, John Ebel and Kunihiko Shimazaki are also acknowledged.

This research was supported by the Division of Earth Sciences, National Science Foundation, NSF Grant EAR76-14262 and NSF Grant EAR77-14675. 


\section{References}

Chase, C. G., 1971. Tectonic history of the Fiji plateau, Geol. Soc. Am. Bull., 82, 3087--3110.

Chung, W.-Y. \& Kanamori, H., 1976. Source process and tectonic implications of the Spanish deepfocus earthquake of March 29, 1954, Phys. Earth planet. Int., 13, 85-96.

Chung, W.-Y. \& Kanamori, H., 1977. Focal mechanism of the New Hebrides earthquake of January 19 , 1969 and ridge subduction under the New Hebrides arc, Abstract, Abstracts with programs, vol. 9, no. 4, 1977 February, Cordilleran Section, 73rd annual meeting, The Geological Society of America.

Chung, W.-Y. \& Kanamori, H., 1978. A mechanical model for plate deformation associated with aseismic ridge subduction in the New Hebrides Arc, Tectonophys., in press.

Den, N., Ludwig, W. J., Murauchi, S., Ewing, M., Hotta, H., Asanuma, T., Yoshii, T., Kabotera, A. \& Hagiwara, K., 1971. Sediments and structure of the Earuipik-New Guinea rise, J. geophys. Res., $76,4711-4723$.

Dubois, J., 1971. Propagation of $P$ waves and Rayleigh waves in Melanesia: structural implications, J. geophys. Res., 76, 7217-7240.

Fukao, Y. \& Abe, K., 1971. Multi-mode Love waves excited by shallow and deep earthquakes, Bull. earthquake Res. Inst., 49, 1-12.

Helmberger, D. V., 1974. Generalized ray theory for shear dislocations, Bull. seism. Soc. Am., 64, 45-64.

Isacks, B. L. \& Molnar, P., 1971. Distribution of stresses in the descending lithosphere from a global survey of focal-mechanism solutions of mantle earthquakes, Rev. Geophys. Space Phys., 9, 103174.

Isacks, B. L. \& Barazangi, M., 1977. Geometry of Benioff zones: lateral segmentation and downwards bending of the subducted lithosphere, in Island arcs deep sea trenches and back-arc basins, eds Talwanji, M. \& Pitman, W. C. III, AGU Maurice Ewing Series 1.

Isacks, B., Barazangi, M., Stephens, C., York, J., Louat, R., Pascal, G., Pontoise, B. \& Dubois, J., 1977. Geometry of the lithosphere subducted beneath the central New Hebrides island arc, Abstract, EOS, 58, 1977 June.

Johnson, T. \& Molnar, P., 1972. Focal mechanisms and plate tectonics of the southwest Pacific, J. geophys. Res., 77, 5000-5031.

Kanamori, H., 1970a. Synthesis of long period surface waves and its application to earthquake source studies - Kurile Islands earthquake of October 13, 1963, J. geophys. Res., 75, 5011-5027.

Kanamori, H., 1970b. Velocity and $Q$ of mantle waves, Phys. Earth planet. Int., 2, 259-275.

Kanamori, H., 1970c. The Alaska earthquake of 1964 : radiations of long-period surface waves and source mechanism, J. geophys. Res., 75, 5029-5040.

Kanamori, H., 1971. Focal mechanism of the Tokashi-Oki earthquake of May 16, 1968: contortion of the lithosphere at a junction of two trenches, Tectonophys., 12, 1-13.

Kanamori, H., 1972. Tectonic implications of the 1944 Tonankai and the 1946 Nankaido earthquakes, Phys. Earth planet. Int., 5, 129-139.

Kanamori, H. \& Cipar, J. J., 1974. Focal process of the great Chilean earthquake of May 22, 1960, Phys. Earth planet. Int., 9, 128-136.

Kanamori, H. \& Stewart, G., 1976. Mode of the strain release along the Gibbs fracture zone, mid-Atlantic ridge, Phys. Earth planet. Int., 11, 312-332.

Karig, D. E., 1972. Remnant arcs, Geol. Soc. Am. Bull., 83, 1057-1068.

Karig, D. E. \& Mammerickx, J., 1972. Tectonic framework of the New Hebrides island arc, Marine geology, 12, 187-205.

Kelleher, J. \& McCann, W., 1976. Buoyant zones, great earthquakes and unstable boundaries of subduction, J. geophys. Res., 81, 4885-4896.

Langston, C. A. \& Helmberger, D. V., 1975. A procedure for modelling shallow dislocation sources, Geophys. J. R. astr. Soc., 42,117-130.

Ludwig, W. J., Murauchi, S., Den, N., Buhl, P., Aotta, H., Ewing, M., Asamuma, T., Yoshii, T. \& Sakajiri, N., 1973. Structure of East China Sea-West Philippine Sea margin off southern Kyushu, Japan, J. geophys. Res., 78, 2526-2536.

Luyendyk, B. P., Bryan, W. B. \& Jezek, P. A., 1974. Shallow structure of the New Hebrides island arc, Geol. Soc. Am. Bull., 85, 1287-1300.

Mallick, D. I. J., 1973. Some petrological and structural variations in the New Hebrides, in The Western Pacific: island arcs, marginal seas, geochemistry, pp. 193-211, ed. Coleman, P. J., University of Western Australia Press, Nedlands.

Menard, H. W. \& Chase, T. E., 1970. Fracture zones, in The sea, vol. 4, pp. 421-443, ed. Maxwell, A. E., Interscience Pubs., Inc., New York. 
Mitchell, A. H. G. \& Warden, A. J., 1971. Geological evolution of the New Hebrides island arc, Geol. Soc. London J., 127, $501-529$.

Morgan, W. J., 1971. Convection plumes in the lower mantle, Nature, 280, 42-43.

Morgan, W. J., 1972. Deep mantle convection plumes and plate motions, Am. Ass. petr. Geol. Bull., 56, $203-213$.

Morgan, W. J., 1973. Plate motions and deep mantle convection, in Studies in Earth and space sciences (Hess Volume), eds Shagam, R. et al., Geol. Soc. Am. Mem., 132, 7-22.

Plafker, G., 1972. Alaskan earthquake of 1964 and Chilean earthquake of 1960, implications for arc tectonics, J. geophys. Res., 77, 901-925.

Santo, T., 1970. Regional study on the characteristic seismicity of the world: part III - New Hebrides islands regions, Bull. earthquake Res. Inst. , 48, 1-18.

Shimazaki, K., 1974. Nemuro-Oki earthquake of June 17, 1973: a lithospheric rebound at the upper half of the interface, Phys. Earth planet. Int., 9, 314-327.

Smith, S. W., 1972. The anelasticity of the mantle, Tectophys., 13,601-622.

Stauder, W., 1968. Tensional character of earthquake foci beneath the Aleutian Trench with relation to sea-floor spreading, J. geophys. Res., 73, 7693-7701.

Stauder, W., 1976. Fault motion in the larger earthquakes of the Kurile--Kamchatka arc and of the Kurile-Hokkaido corner, J. geophys. Res., 81, 297-308.

Tsai, Y. B. \& Aki, K., 1969. Simultaneous determination of the seismic moment and the attenuation of seismic waves, Bull. seism. Soc. Am., 59, 275-287.

Vogt, P. R., 1973. Subduction and aseismic ridges, Nature, 241, 189-191.

Vogt, P. R., Lowrie, A., Bracey, D. \& Hey, R., 1976. Subduction of aseismic oceanic ridges: effects on shape, seismicity and other characteristics of consuming plate boundaries, Geol. Soc. Am. Spec. Paper, 172, 59 pages.

Wilson, J. T., 1965. Evidence from ocean islands suggesting movement in the earth, Phil. Trans $R$. Soc. Lond. $A, 258,145-165$. 